\title{
Hubungan Antara Konsumsi Bahan Bakar dengan Berbagai Perubahan Kecepatan pada Motor Diesel Penggerak Kapal
}

\author{
Budi Utomo \\ Program Studi D3 Teknologi Perancangan dan Konstruksi Kapal, Sekolah Vokasi Universitas Diponegoro \\ Jl. Prof. Soedarto, SH, 50275 Tembalang \\ E-mail: budiutomo_undip@yahoo.com
}

\begin{abstract}
Abstrak
Pemakaian motor Diesel sebagai mesin penggerak kapal pada saat ini semakin meluas, karena konsumsi bahan bakar lebih efisien apabila dibandingkan dengan motor bensin. Terdapat korelasi antara konsumsi bahan bakar, kecepatan dan putaran mesin selalu saling berkaitan dan tidak bisa dipisahkan. Dengan meningkatnya putaran mesin akan berpengaruh pada peningkatan daya. Tujuan dari penelitian untuk mengetahui daya, kebutuhan bahan bakar mesin diesel pada berbagai variasi putaran mesin diesel pada kapal berbobot mati 120 DWT. Pada pengujian performasi mesin Diesel pada kapal 120 DWT ini didapatkan hasil setiap kenaikan daya $10 \%$ mengalami peningkatan putaran rpm rata-rata sebesar $9,86 \%$, peningkatan kebutuhan bahan bakar rata-rata sebesar $27,3 \%$, peningkatan temperatur air pendingin mesin rata-rata sebesar $12,20 \%$ dengan total kebutuhan bahan bakar sebanyak 629,5 Liter.
\end{abstract}

Diterima: 13-03-2020; Direvisi: 28-08-2020; Dipublikasi: 01-09-2020

Kata kunci: Daya Mesin; Kecepatan Kapal; Konsumsi bahan bakar; Putaran mesin

\begin{abstract}
The Diesel motors ship driving machines at this time is expanding, because fuel consumption is more efficient when compared with gasoline motors. Correlation between the fuel consumption, speed and rpm of the machine is always interconnected and inseparable. With increasing engine rotation will have an effect on the increase in power. The purpose of the research to find out the power, fuel needs of Diesel engines on various variations of diesel engine rpm on ships weighing 120 DWT. In diesel engine performance testing on 120 DWT ships, each 10\% increase in power increased by an average rpm $9.86 \%$, an average increase in fuel needs $27.3 \%$, an average increase in water cooling temperature engine $12.20 \%$ with a total fuel need 629.5 Liters.
\end{abstract}

Key words: Power Engine; Speed vessel; Fuel consumption; Engine rotation

\section{Pendahuluan}

Bidang ilmu pengetahuan rekayasa dan teknologi telah banyak mengalami perkembangan, sehingga dalam segi kemajuan dalam bidang perindustrian yang terutama menyangkut persoalan permesinan, beberapa peralatan atau mesin diciptakan guna mempermudah dan menunjang serta meningkatkan kegunaan dalam memenuhi kebutuhan manusia. Tidak menutup kemungkinan pada bidang otomotif, yaitu dalam penggunaanya perlu menganalisa berdasarkan pengetahuan dalam hal permesinan, hal itu baik agar selama proses pengoperasian suatu mesin dapat efektif dan efisien. Pada saat ini otomotif khususnya pada mesin Diesel mengalami suatu perkembangan yang baik, karena didukung oleh tingkat kemajuan teknologi dan memiliki suatu kualitas pekerja yang semakin meningkat. Penggunaan mesin Diesel pada era jaman sekarang ini juga semakin banyak karena konsumsi bahan bakar motor Diesel lebih irit jika dibandingkan dengan motor berbahan bakar bensin. Ketika beroperasi mesin tersebut bergantung pada temperatur yang diproduksi ketika mesin melakukan kompresi untuk meningkatkan volume pembakaran bahan bakar di ruang bakar [1].

Pada jenis mesin Diesel, bahan bakar yang digunakan, diinjeksikan masuk ke ruang bakar pada saat akhir langkah kompresi. Setelah terjadi pemasukan udara kedalam silinder selanjutnya dikompresi hingga tekanan dan suhu udara mengalami kenaikan. Kenaikan ini mengakibatkan terjadinya proses pembakaran bahan bakar tanpa alat penyala dan terbakar sendiri. Guna mendapatkan tekanan dalam silinder yang tinggi ketika putaran mesin menurun, banyaknya udara yang masuk harus cukup besar dengan menggunakan suatu valve yang disebut dengan throttle valve untuk 
mengatur suatu aliran dari udara yang terhisap tidak berlebihan. Disini dapat dikatakan dalam sebuah sistem mesin Diesel, luaran mesinnya dapat dilakukan pengontrolan oleh sebuah alat yang digunakan untuk mengontrol banyaknya konsumsi bahan bakar yang dibutuhkan. Mesin Diesel termasuk kelompok motor pembakaran dalam, karena proses pembakaran bahan bakar terjadi di ruang bakar didalam motor itu sendiri. Proses pembakaran yang terjadi pada bahan bakar oleh karena akibat proses kompresi / penekanan volume udara didalam silinder berkisar antara 30 sampai dengan $40 \mathrm{Kg} / \mathrm{cm}^{2}$ dengan temperatur $600^{\circ} \mathrm{C}$ sampai dengan $800^{\circ} \mathrm{C}$ untuk selanjutnya bahan bakar disemprotkan ke ruang bakar dalam bentuk kabut pada suhu udara dan tekanan tinggi [2]. Dalam pemilihan motor Diesel perlu adannya beberapa pertimbangan sehingga terpilihlah spesifikasi mesin yang ideal. Parameter pemilihan mesin Diesel diantaranya: (1) rute pelayaran dari kapal tersbut (2) konsumsi bahan bakar kapal, (3) operasional penggunaan mesin kapalnya.

Sebagai salah satu daya dukung untuk menggerakkan kapal diperlukan suatu usaha untuk meningkatkan kecepatan yang diinginkan guna mencapai kecepatan efektif yang sesuai dengan yang direncanakan. Adapun dalam hal ini daya mesin seperti yang dijelaskan tadi terdapat dua jenis diantaranya yaitu daya yang bersifat berkelanjutan atau kontinyu dan daya yang bersifat paling tinggi atau maksimum. Sumber daya yang dihasilkan secara berkelanjutan tersebut untuk memperoleh kecepatan dinas yang diharapkan mampu mencapai kecepatan terbaik serta sumber daya tertinggi guna memenuhi kecepatan tertinggi atau kecepatan dalam percobaan. Yang perlu diperhatikan terdapat beberapa jenis dalam sebuah istilah kekuatan / daya (horse power) sebagai daya yang dihasilkan oleh mesin pada dunia perkapalan diantaranya yaitu: IHP (Indicator Horse Power), BHP (Brake Horse Power), SHP (Shaft Horse Power), DHP (Delivery Horse Power) dan EHP (Efective Horse Power). IHP dimana hal tersebut ditentukan berdasarkan besarnya tekanan yang berada pada ruang bakar isi silinder atau diperhitungkan menurut diagram kerja mesin. BHP sesuai yang dimaksud diatas merupakan suatu daya yang diperuntukan memutar poros sehingga nilainya dapat lebih kecil dari IHP atau pada bagian ini sering disebut juga kehilangan tenaga dalam silinder. Sedangkan SHP penentuannya berdasarkan torsi pada poros dan EHP yang dimaksud diatas merupakan daya yang termasuk dalam salah satu daya pendukung untuk menggerakkan propeller kapal ketika beroperasi [2].

Mesin Diesel adalah alat yang dapat menghasilkan tenaga serta dapat mengkonversi sumber energi panas menjadi suatu daya tenaga mekanik melalui sistem pembakaran bahan bakar [3]. Jika dilihat berdasarkan jenis pembakaran motor bakarnya dibedakan menjadi beberapa macam yaitu sistem motor pembakaran dalam (internal combustion engines) dan sistem motor pembakaran luar (external combustion engines). Motor pembakaran luar merupakan suatu alat dimana energinya dapat digunakan guna menghasilkan suatu kerja atau daya mekanik didapatkan menggunakan metode pembakaran bahan bakar dilakukan pada ruang bakar di luar motor tersebut, seperti contohnya pada mesin uap, mesin turbin uap. Sedangkan disisi lain pada motor pembakaran dalam didefiniskan merupakan suatu motor yang dayanya ditujukan guna menghasilkan kerja mekanik diperoleh dari hasil pembakaran bahan bakar yang dilakukan di dalam motor itu sendiri, seperti motor Diesel dan motor bensin. Motor empat langkah dalam hal ini merupakan suatu motor yang kerjanya setiap satu silindernya mendapatkan satu kali pembakaran dan membutuhkan empat kali pergerakan piston yaitu dua kali bergerak ke bawah, dua kali bergerak keatas, serta dua kali putaran poros engkol.

Siklus Diesel empat tak adalah sebagai berikut: (1) Tak Satu /Langkah hisap, piston bergerak dari top dead centre menuju ke bottom dead center. Klep in membuka, klep out tertutup otomatis, terjadi proses penghisapan udara murni masuk kedalam silinder mesin melalui intage manifold, poros engkol berputar $180^{\circ}$. (2) Tak dua/Langkah kompresi, piston bergerak dari bottom dead center ke top dead center, klep in dan klep out tertutup maka kapasitas udara yang telah dikompresikan oleh piston dalam ruang bakar silinder yaitu antara 3/4 atau lebih dari seluruh volume silinder. 
Dalam hal ini kompresi udara (kepadatan) yang terjadi sampai dengan tekanan tinggi yaitu antara $35-40 \mathrm{~kg} / \mathrm{cm}^{2}$, poros engkol berputas $180^{\circ}$. (3) Tak tiga/Langkah usaha, klep in dan klep out tertutup sedikit piston mencapai top dead center, panas udara yang dikompresi suhu mencapai antara $600^{\circ} \mathrm{C}$ sampai dengan $800^{\circ} \mathrm{C}$, kemudian pada saat bersamaan injector nozzle menyemprotkan bahan bakar solar yang berbenatuk kabut sehingga langsung terbakar. Setelah terjadi pembakaran bahan bakar maka tekanan dalam silinder dengan cepat naik mencapai tekanan 50 $\mathrm{kg} / \mathrm{cm}^{2}$ sehingga mendorong piston dari top dead center menuju ke bottom dead center menghasilkan suatu langkah usaha dari motor tersebut.(4) Tak Empat/ Langkah pembuangan, merupakan langkah dimana klep in tertutup, klep out terbuka. Piston bergerak dari bottom dead center ke top dead center, maka yang terjadi sisa-sisa pada proses pembakaran dibuang melalui katup buang dan kemudian diteruskan menuju manifold jalur pembuangan [4]. Berdasarkan siklus kerja mesin Diesel tersebut maka dapat disimpulkan dalam satu siklus dibutuhkan empat langkah piston dan dua kali putaran poros engkol. Distribusi bahan bakar terdapat suatu sistem, dan menggambarkan jalurnya bahan bakar dari dalam tangki penyimpanan kemudian dialirkan ke ruang bakar silinder dan dikabutkan oleh suatu alat pompa yang sering disebut juga injection pump $[5,6]$. Sistem ini termasuk kedalam sistem yang vital karena menunjang keberhasilan dari pengoperasian motor Diesel, jika kita melihat bahwa sangat berkaitan antara penyediaan tenaga dengan bahan bakar [7,8]. Pada sistem pengabutan bahan bakar ini juga sebaiknya cukup sempurna, jika dilihat apabila suatu sistem pengabutan bahan bakar yang tidak sempurna terjadi sehingga mengakibatkan terjadinya kekurangan suplai tenaga atau tidak maksimalnya sistem bahan bakar tersebut yang dalam hal ini akan menimbulkan kerugian tenaga serta mempengaruhi hasil dari daya motor, lihat Gambar 1.

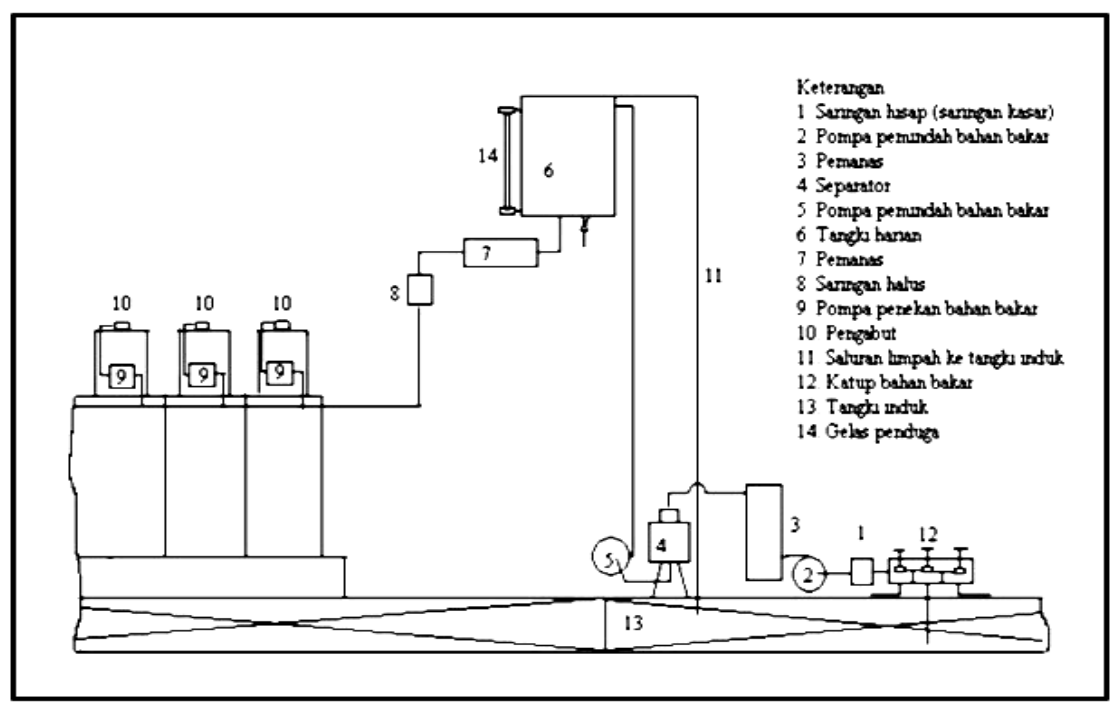

Gambar 1. Sistem bahan bakar pada unit besar

Adapun suatu sistem bahan bakar memiliki fungsi diantaranya untuk: (1) Menghantarkan bahan bakar dari suatu tangki harian menuju ke ruang bakar mesin, (2) Melakukan kontroling atau pengaturan terhadap jumlah bahan bakar yang mengalami pengabutan sesuai dengan kapasitasnya, (3) Melakukan pengaturan saat proses pengabutan yang tepat, (4) Menentukan pengaturan lamanya pengabutan, (5) Melakukan proses pengabutan bahan bakar dan menghantarkannya ke dalam ruang bakar silinder, (6) Melakukan penakaran untuk kemudian dilanjutkan ke proses pendistribusian bahan bakar ke setiap ruang bakar silinder $[9,10]$. Adapun berdasarkan pemaparan literatur diatas maka dapat dirumuskan bahwa hipotesis sementara adanya pengaruh antara kebutuhan baham bakar dengan putaran mesin yang terdapat pada mesin Diesel kapal dengan bobot mati 120 DWT tersebut. Hal ini merupakan suatu keterbaruan 
Budi Utomo./Jurnal Rekayasa Mesin p-ISSN: 1411-6863, e-ISSN: 2540-7678

Vol.15|No.2|163-170|Agustus|2020

untuk kapal kelas menengah sedang, karena ukuran mesin Diesel kapal dengan bobot mati 120 DWT cukup belum terungkap pada penelitian sebelumnya. Tujuan dari penelitian ini adalah untuk mengetahui daya, kebutuhan bahan bakar mesin diesel pada berbagai variasi putaran mesin Diesel pada kapal berbobot mati 120 DWT.

\section{Material dan Metodologi}

Dalam hal ini akan dibahas beberapa hal mengenai sampel penelitian, variable penelitian, perangkat penelitian/pengambilan data dan proses pengambilan data:

1. Sampel

Dalam penelitian ini diambilkan sampel dari sebuah mesin Diesel sebagai Penggerak Utama Kapal (Main Engine) dengan data teknis sebagai berikut:

$$
\begin{array}{ll}
\text {-Daya yang dihasilkan } & =403 \mathrm{KW}=540,21 \mathrm{Hp} \\
\text {-Putaran mesin } & =1800 \mathrm{rpm} \\
\text {-Diameter Silinder } & =137 \mathrm{~mm} \\
\text {-Langkah Piston } & =152 \mathrm{~mm} \\
\text {-Jumlah Silinder } & =12
\end{array}
$$

Mesin tersebut dipasang pada kapal yang berbobot mati 120 DWT.

2. Variabel Penelitian

Pemilihan variabel merupakan suatu tatanan parameter utama yang mempengaruhi luaran dari penelitian yang akan dicapai. Pada penelitian ini ditetapkan variable penelitian adalah sebagai berikut :

- Variabel bebas

Sesuai dengan tujuan penelitian yang akan dicapai yaitu untuk mengetahui kebutuhan bahan bakar pada berbagai putaran, maka variable bebas dalam penelitian ini adalah kebutuhan bahan bakar selama mesin penggerak dioperasikan pada putaran tertentu.

- Variabel Kendali

Sedangkan sebagai variabel kendali dalam penelitian ini adalah putaran mesin, mulai putaran idle sampai putaran maksimum.

\section{Pengambilan Data}

Dari sini akan diawali dengan metode pengambilan data, lalu kemudian peralatan pengambilan data dan dilanjutkan dengan pelaksanaan pengambilan data.

a. Metode atau Pengambilan Data

Proses pengambilan data digunakan metode eksperimen yaitu menyiapkan sarana eksperimen sebuah mesin Diesel penggerak kapal. Sebelum digunakan sebagai peralatan pengambilan data, pada mesin tersebut diadakan pengujian pendahuluan. Penelitian ini dilaksanakan di Perusahaan galangan kapal PT. Janata Marina Indah Semarang, dengan data yang diambil berupa :

- Putaran mesin pada berbagai tingkatan

- Kebutuhan bahan bakar pada berbagai tingkat putaran mesin.

- Data yang didapat kemudian di catat dalam format pencatat data.

b. Peralatan Pengambilan Data

Peralatan pengambilan data yang digunakan dalam penelitian ini antara lain : 
Budi Utomo./Jurnal Rekayasa Mesin p-ISSN: 1411-6863, e-ISSN: 2540-7678

Vol.15|No.2|163-170|Agustus|2020

- Tachometer (alat pengukur putaran mesin), alat ini digerakkan secara mekanik menggunakan roda gigi dengan skala penunjukan mulai $0 \mathrm{rpm}$.

- Flow meter ( alat pengukur penggunaan bahan bakar).

- Pencatat waktu ( stop watch), yang digunakan dalam penelitian ini memakai sistem digital dengan ketelitian pengukuran sampai 0,01 detik.

Alat ini digunakan untuk menentukan waktu yang digunakan untuk mengalirkan pemakaian bahan bakar pada berbagai putaran, lihat Tabel 1 .

c. Pelaksanaan Pengambilan Data

Pengambilan data dilakukan setelah sistem instalasi dipersiapkan dan diyakini dapat beroperasi dengan baik. Langkah persiapan yang dilakukan berupa pemasangan instalasi pengujian. Agar mendapatkan data yang akurat maka perlu adanya koordinasi yang baik dan tepat kepada setiap petugas dengan peratalatan yang dibawa masing-masing oleh setiap petugas. Data yang diambil dimulai dari kondisi putaran idle tanpa perlakuan khusus dengan mencatat kebutuhan bahan bakar saat beroperasi dan debit aliran dari sistem tersebut. Setelah dilakukan pengujian putaran idle dilanjutkan pada putaran sesuai ketentuan yang ditetapkan.

Tabel 1. Data Prestasi Mesin Diesel Penggerak Kapal

\begin{tabular}{lccc}
\hline Prosentase Beban & Daya $(\mathrm{Kw})$ & Rpm & Temperatur Gas Buang ${ }^{0} \mathrm{C}$ \\
\hline Beban Lebih & 458 & 1853 & 397 \\
Daya Normal & 407 & 1802 & 381 \\
$90 \%$ & 351 & 1741 & 364 \\
$75 \%$ & 276 & 1637 & 336 \\
$65 \%$ & 161 & 1432 & 274 \\
$25 \%$ & 64 & 1138 & 190 \\
Tanpa Beban & - & 687 & 103 \\
\hline
\end{tabular}

\section{Hasil dan Pembahasan}

Minyak Diesel mempunyai berat jenis 0,85 sampai 0,95 dengan titik didih antara $200^{\circ} \mathrm{C}$ sampai $350^{\circ} \mathrm{C}$ dan nilai pembakaran $(\mathrm{Np}) 9500-10000 \mathrm{Kkal} / \mathrm{kg}$. Kualitas minyak Diesel dinyatakan dengan kadar cetana $\left(\mathrm{C}_{10} \mathrm{H}_{34}\right)$ yang bernilai 40 sampai 70 [11]. Titik nyala $65{ }^{\circ} \mathrm{C}-70{ }^{\circ} \mathrm{C}$ dan viskositasnya $1,5 \mathrm{Ns} / \mathrm{m}^{2}-3,5 \mathrm{Ns} / \mathrm{m}^{2}$ [12]. Kebutuhan bahan bakar spesifikmerupakan banyaknya fuel consumsion yang dibutuhkan tiap jam per tenaga daya dan besarnya ditentukan dengan persamaan:

$$
B=\frac{G f}{N}=\frac{l}{Q e . \eta}=\frac{3600 \times 75}{427}=\frac{632\left(\frac{\mathrm{kg}}{\mathrm{jam}}\right)}{Q e . \eta(P s)}
$$

Dimana B $=$ Kebutuhan bahan bakar spesifik, $\mathrm{Gf}=$ Jumlah bahan bakar yang dibutuhkan $(\mathrm{kg} / \mathrm{jam}), \mathrm{Qe}=$ Nilai kalor bahan bakar ( Kcal/kg ),N = Daya yang dihasilkan motor, $\eta=$ Efisiensi ( \% ) Harga B yang lebih rendah menunjukkan efisiensi yang lebih tinggi. Penurunan kecepatan jika $\mathrm{n}_{\mathrm{o}}$ menyatakan kecepatan tanpa beban, $\mathrm{n}_{1}$ kecepatan beban penuh yang sering disebut kecepatan normal, maka penurunan kecepatan putaran per menit secara sederhana adalah sama dengan $\mathrm{n}_{0}-\mathrm{n}_{1}$. Kalau penurunan kecepatan dinyatakan dengan $\mathrm{p}$ [13], maka dapat dihitung sebagai berikut:

$$
\mathrm{P}=\frac{100\left(\mathrm{n}_{0}-\mathrm{n}_{1}\right)}{\mathrm{n}_{1}}
$$


Budi Utomo./Jurnal Rekayasa Mesin p-ISSN: 1411-6863, e-ISSN: 2540-7678

Vol.15|No.2|163-170|Agustus|2020

Dimana $\mathrm{p}=$ penurunan kecepatan (\%), $\mathrm{n}_{0}=$ Kecepatan tanpa beban (putaran/menit atau rpm), $\mathrm{n}_{1}=$ Kecepatan dengan beban (putaran/menit atau rpm) dalam percobaan mesin kapal dengan putaran $=1950 \mathrm{rpm}$ sampai dengan $2000 \mathrm{rpm}$, dengan perubahan kecepatan (putaran) mesin adalah sebagai berikut:

$\mathrm{p}=\frac{100(2000-1950)}{1950}$

Jadi penurunan kecepatan pada beban penuh $=2,56 \%$.

Dari hasil pengujian kebutuhan bahan bakar mesin Diesel diperoleh data putaran mesin dari idle sampai putaran maksimum; temperatur air pendingin mesin; kebutuhan bahan bakar, kemudian semua data disusun dalam Tabel 2.

Tabel 2. Hubungan kebutuhan bahan bakar pada berbagai putaran mesin.

\begin{tabular}{lcccc}
\hline No & Progresif Speed & Putaran (n) Rpm & Kebutuhan Bahan Bakar (b) / liter & Temperatur air pendingin ${ }^{0} \mathrm{C}$ \\
\hline 1 & $0 \%$ & 750 & 6,5 & 29 \\
2 & $15 \%$ & 1135 & 25 & 35 \\
3 & $25 \%$ & 1350 & 31 & 51 \\
4 & $35 \%$ & 1438 & 45 & 65 \\
5 & $45 \%$ & 1500 & 58 & 75 \\
6 & $55 \%$ & 1638 & 72 & 80 \\
7 & $65 \%$ & 1690 & 86 & 81 \\
8 & $75 \%$ & 1712 & 91 & 83 \\
9 & $85 \%$ & 1750 & 99 & 85 \\
10 & $100 \%$ & 1800 & 116 & 85 \\
\hline
\end{tabular}

Jika dilihat dari data hasil pengamatan yang di plot pada diagram $b-n$, kemudian masing-masing titik dihubungkan dengan garis, maka akan membentuk kurva kasar yang melukiskan karakteristik $\mathrm{b}-\mathrm{n}$. Beberapa cara pendekatan perlu dilakukan guna mendapatkan kurva yang halus dengan tingkat deviasi yang serendah-rendahnya.

Bentuk kurva dasar merupakan acuan utama yang dipakai untuk menentukan bentuk persamaan pendekatan yang dapat diambil atau dipilih dari berbagai macam kemungkinan persamaan pendekatan[14]. Dengan melihat bentuk awal kurva tersebut yang seolah-olah parabolik, maka dapat dipilih pendekatan tipe eksponensial:

$$
\begin{aligned}
& Y^{\prime}=10^{\log y^{\prime}} \text { dan } \log Y \\
& Y^{\prime}=\log a+X \cdot \log b
\end{aligned}
$$

Dalam hal ini nilai $\log$ a dan $\log \mathrm{b}$ dapat ditentukan dengan menggunakan data hasil pengamatan, untuk itu digunakan metode Trend Eksponensial[15].

$$
\begin{aligned}
& \log a=\frac{\left(\epsilon \log Y \cdot \epsilon X^{2}-\epsilon X . \epsilon X \log Y\right)}{n \epsilon X^{2}-(\epsilon X)^{2}} \\
& \log b=\frac{(\epsilon \log X \cdot \epsilon Y-\log Y \cdot \epsilon X)}{n \epsilon X^{2}-(\epsilon X)^{2}} \\
& \mathrm{a}=\frac{\left(\epsilon Y . \epsilon X^{4}-\epsilon X^{2} \epsilon X \log Y\right)}{n \epsilon X^{4}-(\epsilon X)^{2}}
\end{aligned}
$$


Budi Utomo./Jurnal Rekayasa Mesin p-ISSN: 1411-6863, e-ISSN: 2540-7678

Vol.15|No.2|163-170|Agustus|2020

Dari tabel hasil pengamatan yang menunjukkan hubungan antara bahan bakar dan putaran mesin dapat disusun dalam tabel statistik, dapat dilihat pada Tabel 3 .

Tabel 3. Statistik Hasil Pengamatan

\begin{tabular}{ccccccccc}
\hline Putaran & Keb. Bhn bakar (Y) & $\mathrm{Y}^{\prime}$ & $\mathrm{X}$ & $\log \mathrm{Y}$ & $\mathrm{X} \log \mathrm{Y}$ & $\mathrm{X}$ & $\mathrm{X}$ & Log Y \\
\hline 750 & 6,5 & 15,217 & -5 & 0,8129 & $-40,646$ & 25 & 625 & 11,823 \\
1135 & 25 & 19,716 & -4 & 13,979 & $-55,918$ & 16 & 256 & 12,958 \\
1350 & 31 & 256,617 & -3 & 14,914 & $-44,741$ & 9 & 81 & 14,093 \\
1438 & 45 & 333,264 & -2 & 16,532 & $-33,064$ & 4 & 16 & 15,228 \\
1500 & 58 & 432,756 & -1 & 17,634 & $-17,634$ & 1 & 1 & 16,362 \\
1638 & 72 & 561,981 & 0 & 18,573 & 0 & 0 & 17,497 \\
1690 & 86 & 729,793 & 1 & 19,345 & 19,345 & 1 & 16 & 18,632 \\
1712 & 91 & 947,716 & 2 & 1,959 & 39,181 & 4 & 91 & 19,767 \\
1750 & 99 & 123,071 & 3 & 19,956 & 58,869 & 9 & 16 & 20,902 \\
1800 & 116 & 159,821 & 4 & 20,645 & 82,578 & 16 & 256 & 16 \\
& $\mathbf{6 2 9 , 5}$ & & $\mathbf{- 5}$ & $\mathbf{1 6 , 9 3}$ & $\mathbf{0 , 8 9 7 1}$ & & $\mathbf{7 0 8}$ & \\
\hline
\end{tabular}

Selanjutnya data hubungan antara kebutuhan bahan bakar kenaikan putaran mesin dapat ditunjukkan dalam grafik, dapat dilihat pada Gambar 2.

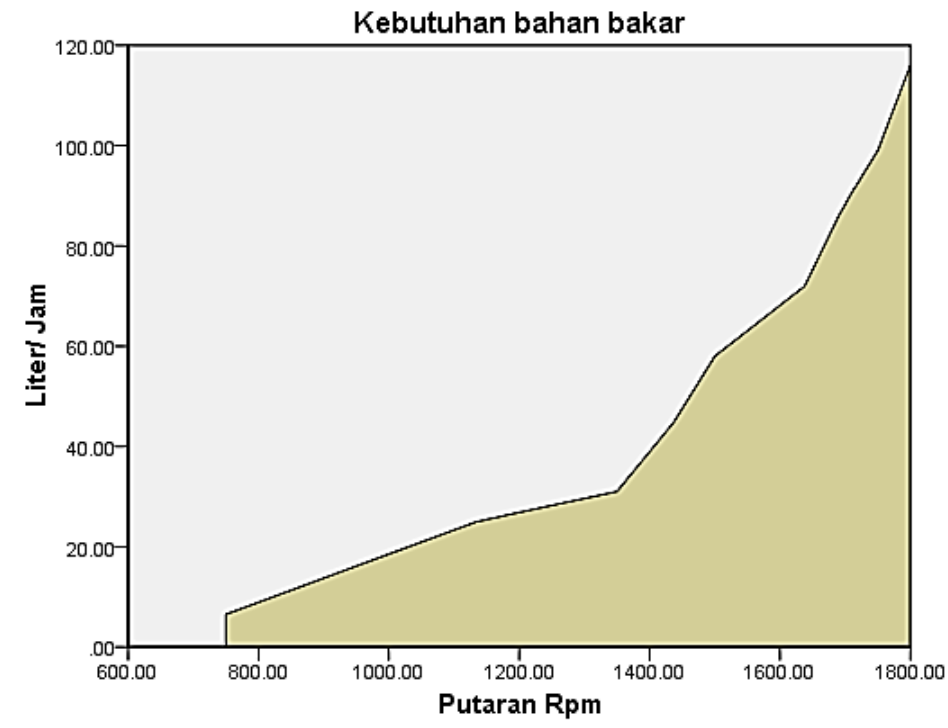

Gambar 2. Grafik kebutuhan bahan bakar pada berbagai tingkat putaran mesin

\section{Kesimpulan}

Berdasarkan hasil pengujian maka dapat ditarik kesimpulan pada pengujian performasi mesin Diesel penggerak kapal 120 DWT ini yaitu meningkatnya putaran mesin akan berpengaruh pada peningkatan daya terlihat dari setiap kenaikan daya 10\% mengalami peningkatan putaran rpm rata-rata sebesar 9,86\%. Kebutuhan bahan bakar akan semakin besar apabila putaran mesin ditingkatkan terlihat dari setiap kenaikan daya 10\% mengalami peningkatan kebutuhan bahan bakar rata-rata sebesar 27,3\%. Trend grafik kebutuhan bahan bakar yang dihasilkan menunjukan peningkatan dengan total kebutuhan bahan bakar sebanyak 629,5 Liter. Dalam pengoperasian mesin seyogyanya diatur pada putaran yang sesuai dengan kebutuhan kecepatan kapal sehingga akan didapatkan efisiensi yang ideal, terlihat dari temperatur air pendingin yang dihasilkan dari setiap kenaikan daya 10\% mengalami peningkatan temperature rata-rata sebesar $12,20 \%$ dan terhitung masih stabil. 
Budi Utomo./Jurnal Rekayasa Mesin p-ISSN: 1411-6863, e-ISSN: 2540-7678

Vol.15|No.2|163-170|Agustus|2020

\section{Daftar Pustaka}

[1] Adji, S.W. Engine Propeller Matching, E-book, 2005, p 345

[2] Arismunandar, W., Tsuda, K. Motor Diesel Putaran Tinggi, Paramudya Paramita , Jakarta, 1983, p 13.

[3] Woodyard. D. Pounder's Marine Diesel Engines and Gas Turbines. Springer. New York, 2009,p 548.

[4] Karyanto. E. Teknik Perbaikan, Penyetelan, Pemeliharaan, Trouble Shooting Motor Diesel. Pedoman Ilmu Jaya, Jakarta, 1986. p 45.

[5] Kuiken, K. Diesel Engines for ship propulsion and power plants from 0 to 100000 kW, Springer, UK. 2016, p 158

[6] Kurniawan, B. T. Perancangan Propeler Self-Propelled Barge. Jurnal Teknik Vomits . 2013. Vol. 2, No.1 p. 23373539.

[7] Maleev. VL.ME.DR.AM. Operasi Pemeliharaan Mesin Diesel. Erlangga. 1986. p 176.

[8] Murdjianto. Motor Penggerak Kapal dan Mesin Bantu. ITS, Jurusan Teknik Perkapalan. 2005. p 34.

[9] Obert, E.F. Internal Combustion Engine. International Text Book Company Seranton Pensylvania. 1968. p 145.

[10] Petrovsky. H. Marine Internal Combustion Engine, Mir Publisher Moscow. 1968. p 15.

[11] Sailor. Marine Diesel engines, Thrane\&Thrane. UK. 2010. p 118.

[12] Suharto, Manajemen Perawatan Mesin, Rimeka Cipta, Jakarta, 1991,p 48.

[13] Sujanto, Pesawat kapal 1. Jakarta. 1982. p 12.

[14] Maleev, V.L., Dr.A.M. M.E., Priambodo.B. Operasi dan Pemeliharaan Mesin Diesel. Erlangga. Jakarta. 1986. P 88.

[15] Yanmar Diesel. Buku Petunjuk Mesin Diesel Yanmar, PT Yanmar Indonesia. Jakarta. 1980. p 27. 